\title{
Core-Binding Factor Subunit Beta
}

National Cancer Institute

\section{Source}

National Cancer Institute. Core-Binding Factor Subunit Beta. NCI Thesaurus. Code

C18027.

Core-binding factor subunit beta (182 aa, $22 \mathrm{kDa}$ ) is encoded by the human CBFB gene.

This protein plays a role in transcriptional regulation. 